\title{
Keeping up with Princess Diana in the Late 90s: A story of denied literacy in remote Central Australian Indigenous communities
}

\author{
MELODIE BAT
}

\section{Introduction}

This paper has a purpose and that purpose is to tell a story. An important story. A story that will sadden you and perhaps give rise to dismay. But it's not a story about a princess. This story takes place, not in the glitz and glamour of Europe with fast cars, great shopping and an avid and enthusiastic paparazzi, but rather in the desert of Central Australia where you need a good four-wheel drive to get home on the dusty roads, where shopping is limited to the basics at the local store, but where people are still avidly following the life and times of the 'Princess of our hearts'.

This paper will tell this story and for many reading this, the story will be enough, for much of what I will say is self-evident, so much so that it seems almost ludicrous to have to analyse the impact of the events I will describe. However, in the interests of academic analysis and to further understand and appreciate the impact of these events, I will firstly frame the context of emergent literacy, give the background to the story and detail the findings of some research which I undertook within this community. Finally, I present the broader implications of these findings and make some recommendations.

\section{The Story}

In a small, one-store community, three hours drive from Alice Springs, two women went to visit the local store. One woman was a member of the school teaching staff and the other was a project officer working for the local education department. The first woman was a local Indigenous woman (Sally) who was born and raised in the community and who was at that time studying to become a teacher. The other woman was a non-Indigenous visiting adviser to the school (the author). These two educators had been working together with mums and little kids exploring ways to make connections between home and school.

We went to the store with the best of intentions and with a small request really - to ask the store to sell reading and writing materials. At that time, the only places in the community where you could access reading and 
writing materials were at the school, the clinic and the local council office all government-run agencies where equipment 'belonged' to that agency. The only place to buy your child a reading book, a colouring-in book, a pencil, was a 250 kilometre drive away.

The community store manager, who was a non-local non-Indigenous man employed by the community-run store committee, was very keen to support the children by giving us $\$ 1000$ for the project officer to buy books, pencils and other materials from Alice Springs. Then the store would add the usual mark-up and sell them. This was great. We were running the project on very limited money - and anyway, we had talked together about shifting literacy to home rather than it 'belonging' to the government. His enthusiastic response was really heartening and we were very happy.

But only for a moment.

Because the next thing he said was that we were not to buy newspapers or magazines because, 'Nobody in this community reads'. And he was very adamant about this. We couldn't get him to change his mind. Sally was very upset by this. As a matter of fact, she and a number of other community members were undertaking further study and training and we knew that community members were literate and interested in current events. One of the things she and I had talked about was the 'Princess Diana' phenomenon and how everyone wanted to know all about this princess. Magazines featuring her were very popular at that time and were passed around the community.

We did not stay around to further argue the point as we had no authority to change the decision.

Just by chance, that storekeeper went on leave and so I added newspapers and magazines to the shopping list. I kept a database of everything I had bought and updated it after each visit to the community. The relieving storekeepers were very keen to be of help and placed a lesser mark-up on the materials to make them more affordable. Some books and textas sold, with the more expensive children's books being bought by a family from a different community who were passing through.

The highest selling items were the magazines and newspapers. In fact, the relieving storekeepers could not keep up with the supply. We had proved that the adults in the community wanted to read for pleasure and information (including information about princesses). Not that we felt we had to prove this to anyone, but we did feel vindicated by this result. Surely, we thought, now the store will have to keep selling newspapers and magazines. However, when the usual storekeeper returned from holidays this supply stopped. 'Not enough profit in it', he said. 


\section{The context for the project}

\section{Literacy levels in the Northern Territory}

There is strong evidence that Australian Indigenous students, especially remote area students in the Northern Territory, are not achieving very high literacy levels. At the time of the project, in 1998 in the Northern Territory, out of all the non-urban, Indigenous ESL students, only two percent achieved the national reading benchmark in Year Three and three percent in Year Five (Northern Territory Department of Education 1999). While there is criticism of the mechanism used to collect this data and participation rates of non-urban Indigenous students are lower than for any other sector, these results are still astonishing.

There is a growing body of research into this situation and various government policies, frameworks and projects have been developed to address this problem. In the search for answers there has been much discussion and many explanations offered. Most of the work is done by the system, within the system and so, many of the children in remote Central Australia only begin to access interventionist programs when they begin school and many of these programs focus only on 'book literacy' with little or no connection to the home literacy that children have already developed.

\section{Defining Terms}

What does the process of learning to be literate look like? I have used some terms in this paper with some quite defined meanings for this context:

emergent literacy

refers to behaviours observed in young children who are still 'playing to learn' either at home or at preschool and are typically aged from birth to five-years-old (Barratt-Pugh and Rohl 2000);

early literacy

refers to a child's literacy development when the formal teaching of literacy begins - at school (Hill, Comber, Louden, Rivalland and Reid vol 2 1998);

\section{family literacy}

refers to literacy at home and is the child's first experience of this world. In this context, in a remote Indigenous Australian community, family means more than just one's immediate family. Rather, it includes the whole community as an extended family connected through kinship, relationship and obligation; 


\section{school literacy}

in Aboriginal communities takes on an extended meaning from the 'mainstream'. Here, the very idea of literacy belongs to the school and this is where you 'catch it'.

It is important to define what emergent literacy behaviours might look like in this particular sociocultural, linguistic and pedagogical context. Dunn (1999) provides us with work in this field, having researched the development of emergent literacy behaviours in Indigenous Australian children, albeit in an urban setting. She identifies six broad areas of emergent literacy and presents assessment tools to support the gathering of data. Dunn's work seeks to define the elements of emergent literacy in order to be able to both research development and to strengthen teaching practice.

1. oral language competence

2. story knowledge

3. book handling knowledge

4. print knowledge

5. book reading knowledge

6. writing knowledge. (Dunn 1999:50)

\section{Language and literacy practices}

The first element in the development of emergent literacy is oral language competence. You need to be able to speak a language before you can read and write it. Durre (1985:18) asserts it cannot be assumed that children from non-literate societies will automatically make the leap from oral language to written language. This is important, because Durre is talking about the development of literacy, rather than the development of emergent literacy behaviours. This distinction becomes important at a later point.

Durre also makes the point that children need exposure to literature and a literacy-based environment before formally learning to read. Interestingly, both Durre (1985) and Dunn (1997) rely on a values-based analysis rather than that of access. The research presented here will clearly show that there is a more fundamental issue here of resource and knowledge.

Children need books to become literate. The benefits and advantages of coming from a literate home life are widely acknowledged (Dunn 1997, 1999, Reid 1997, Hill, Comber, Louden, Rivalland and Reid 1998). 'It is clear that, no matter what the culture, those children with experience of 
books, stories and writing before they go to school, have less trouble learning to be literate than those who do not have that experience' (Dunn 1999:62).

For some Indigenous children these books are not written in their first language. In fact, their first language may not be a written language and they may not learn to speak the language of the books until they start school. Further, in many remote communities, school may be the only place where English is used regularly. Even then, Aboriginal children are likely to use their first language when communicating or playing with each other.

Where children do not have access to books at home before they start school and do not develop emergent literacy behaviours, the school then works to 'bridge the gap'. Whilst there is much that can be written here about bilingual education and the efforts that schools make in this area, this paper is about ensuring that there is no 'gap', thus minimising the need for interventionist strategies.

There are other factors that may impact on the strength of this connection to literacy. Dunn's (1997) research identifies a significant link between literacy competencies at the end of the pre-school year and four years later. In searching for possible determinants of this, Dunn suggests that it is parental values in relation to literacy that make the difference. She states that: 'Aspects of parental values included modelling of positive values in relation to literacy activity, the amount of literacy knowledge that children arrived at school with and parental involvement in school' (1997: 245).

This then shifts the discussion away from the mechanics of reading, away from the pedagogical classroom considerations and moves the discussion back to the family. In a 1997 position paper prepared by the Curriculum Development Unit, Institute for Aboriginal Development (IAD), the rationale behind the IAD adult vernacular literacy program and its benefits are discussed.

Another benefit of adult vernacular literacy in the community will be the expanded awareness of the importance of family literacy practices instead of seeing literacy as a skill acquired only in a classroom. Indigenous adults will become more aware of the importance of home literacy practices, leading to a recognition that successful literacy acquisition in later years is highly dependent on Early Childhood practices such as bedtime story reading, language games and modelling of reading/ writing behaviour. (Institute for Aboriginal Development 1997: 3-4)

A child's literacy life should ideally begin at home, before school commences. Gurrent classroom practices tend to be based on the 
presumption that children who are learning to read are coming from a home life where they have had early exposure to literacy (Hill, Comber, Louden, Rivalland and Reid vol 2 1998). Not only do we expect that children will have had bedtime stories but that children will have observed their families reading and writing in many different situations and for many different purposes - and have been part of this 'literate world' from birth.

\section{The project}

\section{Overview}

This research was conducted over a two year period, commencing in 1998, in three different remote Indigenous communities in Central Australia. The connections and disconnections between home and school were studied with a view to looking for solutions and strategies to meet the needs of communities where literacy levels were low and falling (Bat 2003). This research project focused on before school activities and learning in order to map and detail the knowledge and skills that the children and families need to make an effective transition to school. It explored the literacy lives and learning of twenty-three children and twenty-six family members from three communities over a period of two years. This research reported on the establishment and sustainability of playgroup programs; on supporting literacy development at a community, family and individual level; on the issue of transition to school; and on the methods and strategies for assessment of literacy in this context.

\section{Methodology}

The project officer (myself) was the central researcher. The research methodology itself evolved alongside the programs and with my own growing understandings. Certain elements were there as intentions, but their specifics could not be determined without first beginning the research. For example, it was my intention to assess the children for 'readiness for school' type behaviour and for literacy behaviours. Just what that would look like and the process of developing some sort of useful tool was in itself part of the research. following:

Various data collection techniques were employed. These include the

- Participant observation

- Interviews

- Careful listening to what family members and others were saying

- Trialling assessment techniques

- $\quad$ Observing children's responses and recording through:

- Photographic records 


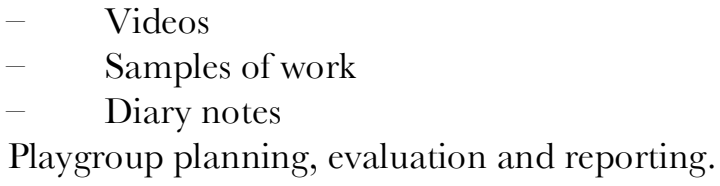

An action research method was integrated into the literacy project in an ongoing way entailing detailed documentation of what was being observed and of my thoughts about the effectiveness of the strategies being employed in the literacy project. In order to validate that my observations were valid, I would consult with parents and colleagues.

These consultations added to my own critical reflections and served to refocus the research. Obviously, one of the critical events that stimulated reflection in this research project was the story of the storekeeper at Community B.

\section{The community}

The community has a population of approximately 250 people and is 250 kilometers from Alice Springs. The local Indigenous language, Anmattyere, is predominately the first language of the children, with a small amount of English being learned by the children before they start school. The major instruction in English occurs in school. Services in the community are the local Council, a Health Centre, a school catering for primary and secondary children, a store and a Women's Centre. At the time of the study, the community had a CDEP (Community Development and Employment Program) scheme. During the project, a program catering to children under the age of five was established in the school. At the time, the school did not have an official preschool program or facilities. There was no childcare service in the community.

This community was established to house Indigenous people who had primarily been working on cattle stations after losing their land to pastoralists. There is still a strong 'cattle station' bank of knowledge in the community and the community run their own cattle. It is always exciting when the community gets the helicopter in to do some mustering before selling off a few head. The community is a cohesive unit of extended families and although there is often social disruption it is generally a peaceful and protective place to live. There are however regular occasions when alcohol is brought into the community and there will be a few days of fighting when the clinic will be run ragged with tending to injuries and evacuations of the more seriously injured. 


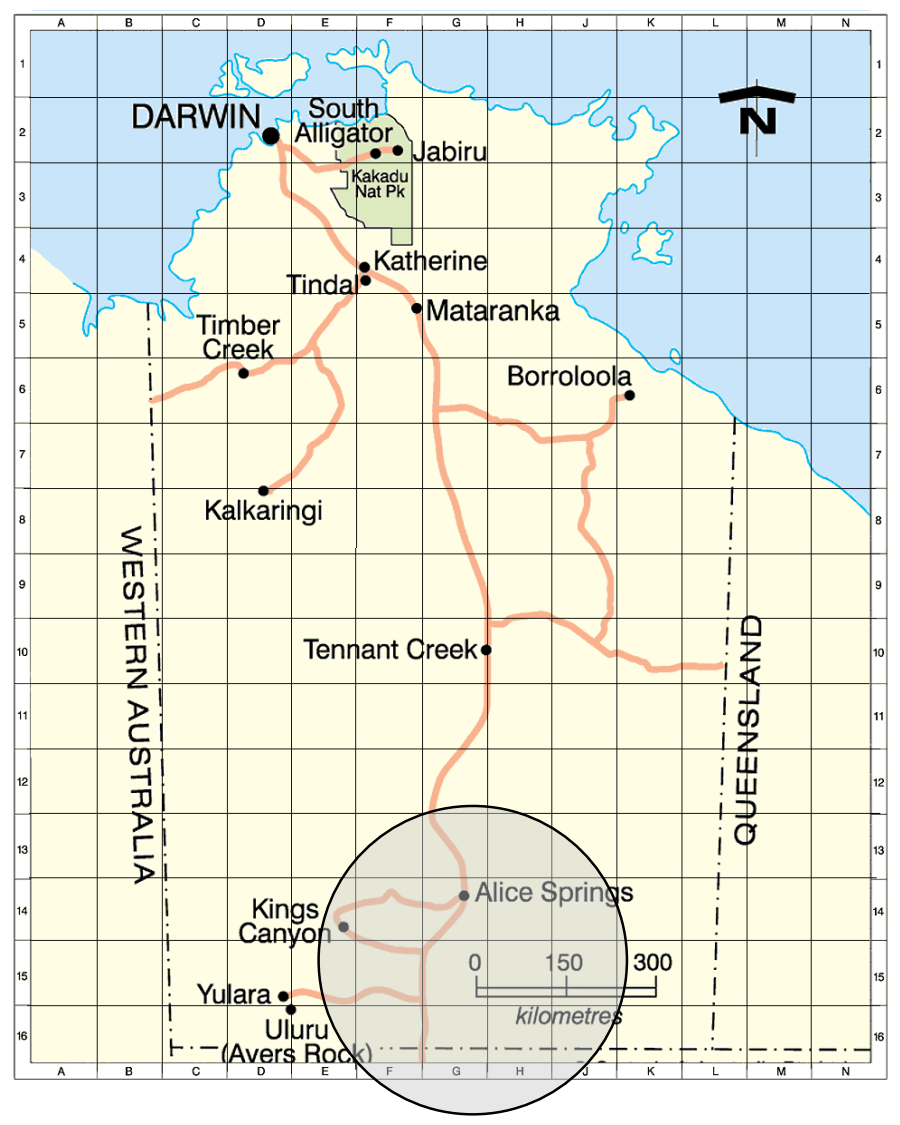

Fig 1: The Northern Territory and the research site

This community was established to house Indigenous people who had primarily been working on cattle stations after losing their land to pastoralists. There is still a strong 'cattle station' bank of knowledge in the community and the community run their own cattle. It is always exciting when the community gets the helicopter in to do some mustering before selling off a few head. The community is a cohesive unit of extended families and although there is often social disruption it is generally a peaceful and protective place to live. There are however regular occasions when alcohol is brought into the community and there will be a few days of fighting when the clinic will be run ragged with tending to injuries and evacuations of the more seriously injured. 


\section{The project families}

The participants from Community B were mostly women and children. Only once did one of the fathers come to playgroup and that was when we held it 'out bush' for the day. Photographic records show him reading, drawing and writing with the children watching. Most of the women had very few literacy skills and at first were embarrassed about this and reluctant to do any writing or reading at all in front of me. Over time this changed and everyone enjoyed writing stories to make our books. All the women spoke English very well and some of the women were undertaking tertiary study.

\section{Participating children}

There were seven children who participated in this project - two girls under two; three girls and one boy aged between two and three and one boy aged between three and four. There were some other little children living in the community who did not participate in this research but who did participate in the playgroups and in the preschool program when it began at the school.

An important characteristic of each child in terms of the research findings was the language/s spoken in the home of that child. This was quite an interesting question to ask the families because it raised the question of definition of 'speaking a language'. In every case, when enrolling a child in the program, when I asked the question 'What languages do you speak at home?' I was asked to clarify the question. In the participant communities there was a very complex linguistic environment within each family and within each house. It was possible to understand a language without speaking it. This was usually the case with a language of one parent who had come into the community from another language group. The children could understand their parent but did not speak their language. In other cases, the children were learning to speak all the languages present in the home. The information gathered and presented in Table 1 represents the languages that the child could hear in the home and records those languages the child was learning to speak. It does not represent the full linguistic diversity surrounding the children. Where the answer was qualified with 'some' as in 'some Pitjantjatjara' or 'some English' I have taken this as a yes and included it in the data. 


\begin{tabular}{|l|l|l|l|}
\hline Language & $\begin{array}{l}\text { Monolingual } \\
\text { speaker }\end{array}$ & $\begin{array}{l}\text { Bilingual } \\
\text { Speaker }\end{array}$ & $\begin{array}{l}\text { Trilingual } \\
\text { Speaker }\end{array}$ \\
\hline Western Aranda & 0 & 0 & 0 \\
\hline Pitjantjatjara & 0 & 0 & 0 \\
\hline English & 0 & $2^{*}$ & 0 \\
\hline $\begin{array}{l}\text { Central/Eastern } \\
\text { Arrernte }\end{array}$ & 0 & 0 & 0 \\
\hline Anmattyere & 2 & $5^{*} \sim$ & 0 \\
\hline Warlpiri & 0 & $3 \sim$ & 0 \\
\hline Subtotals & 2 & 5 & 0 \\
\hline
\end{tabular}

Table 1: Languages the children were learning to speak

\section{Project implementation}

The literacy project was conducted through the local school. One of the women working at the school, Sally, was released from her classroom duties to participate in the playgroups. From the beginning, she and I ran playgroups together, with Sally providing contact with the mothers while I took on more of a trainer role.

A typical 'playgroup' evolved to consist of a fairly standard routine, which was followed for all playgroups at all sites. We found it to be the easiest way to be able to both maintain a consistent routine for the children as well as to allow the flexibility of being able to run a playgroup anywhere.

The 'tarp' was a fundamental resource of this project. I used a big round canvas tarpaulin, specially made from swag tarp, to define our playgroup space. Sitting on the mat was something that the schools were expecting the children to be able to do when they started and so it was something that we could teach the children. Using this tarp allowed us to be able to define our playgroup space no matter our location. In discussion with some mothers and with another teacher, I found that some mothers use a blanket in the same way - to make a 'kitchen table' on the floor/ground and use this as a way to encourage their children to sit on the blanket to eat meals. This tarp also gave us the flexibility to be able to hold a playgroup anywhere - from a more formal school setting to a creek bed. The tarp itself gave the children the connection into the specific learning situation. 


\section{Literacy artefacts in the community}

In order to assess what reading materials existed in the community, I looked for what literature was available for the adults to read, and what writing the children were observing the adults doing. This was a topic that I would bring up in discussion time during playgroups. I found that a lot of people, especially those aged over about thirty or so, were reading anything they could find but that younger people were not reading much at all, other than official paperwork. It was my observation that there was not much reading material available anywhere. The community that is being used a case study for this paper, did not have a local library that people used and the shop did not sell magazines or newspapers. I also looked for whether the children had any role models for writing. Were the adults writing where the children could see? During the two years of my visits to the families and the community. I observed that all reading and writing practices were in English. I observed no writing in the community other than that done at the office, the health centre and the school. I know, from talking with other families, that there is writing in the community, but in other families. There are adults doing tertiary studies in the community - however, all their assignment work is usually done off-community. In view of these observations, and through discussion with the women, we decided to try and do something about this situation.

One strategy I employed was simply to give the families story books to read with the children. Some of these books were donated, some bought, some we made. None of the bought, published books survived for more than the week between visits and I never saw any books that the families had bought themselves. The books that lasted were the ones we made that had photographs of the families and were laminated and heavy duty stapled. At the end of the project, Sally commented to me in discussions over the content of the project's final report, that they had one book in their house, 'Making Damper', made during the project. Her daughter was coming home from school frequently and asking for that book to be read to her. Sally said that she had to 'hide' the book away so that it didn't get taken and lost. This came after 18 months of the 'Targeting Early Literacy - Family and School' project running in the community.

This project was targeted at supporting families to develop their own family literacy rather than having them rely on someone from outside the community to bring in the materials. To investigate the issue of community demand I instigated a trial with the local store with the aim of perhaps initiating a change at a community level rather than on an individual family level. This issue was discussed during playgroup times and then discussed in greater depth between Sally and myself, with the results as depicted in the opening story. 


\section{Findings and discussion}

\section{Frameworks for understanding}

In order to fully appreciate the impact of this one decision made by this one store person, I would like for a moment to travel to Europe and consider a model of capitals and capabilities proposed by Schuller, Bynner and Feinstein (2004) in a paper developed by the Centre for Research in the Wider Benefits of Learning.

Very briefly, their model is that there is interconnectedness between the more traditional economic notion of capital and the more recent notion of capability in terms of returns to learning. If capital is based on the development of assets, (social, cultural and psychological as well as financial and human) and capability is the potential that individuals may possess to do or to be, then the interconnectedness can be explored on a an individual and community level. Schuller et al represent this interplay using the following diagram, Figure 1 below, (2004:4).

Schuller et al use the concept of social exclusion or integration to expand their model, and cite Sen, who argues that 'variation in these capabilities is the underlying cause of inequity' (Sen, cited in Schuller, Bynner and Feinstein 2004: 3). The authors further represent the process of social exclusion or integration through the diagram, Figure 3 below, (Schuller, Bynner and Feinstein 2004:7).

What these two diagrams give us is a framework to understand the wider implications of the delayed or non-development of emergent literacy skills of the children in this case study. A lack of education resources and social services, combined with all the other factors listed, will present obstacles to the development of capability, which will then impact on social integration, which further impacts on the development of individual and community human capital.

\section{Three Findings from the family literacy project}

Each of these findings is considered in turn and discussed in relation to the two models presented.

\section{Finding 1: Remote Indigenous people in Central Australia read for pleasure and are interested in the current events of the day}

My diary notes taken throughout this research project show a clear and consistent record of the Indigenous people in Community B reading for pleasure and discussing what they are reading. Sometimes this was gossip from magazines, at other times this included political discussions that were national as well as local in nature. In the light of the reaction of the store 
manager, I felt that it was important to note this in order to have data to counteract any generalization about the literacy interests of the community.

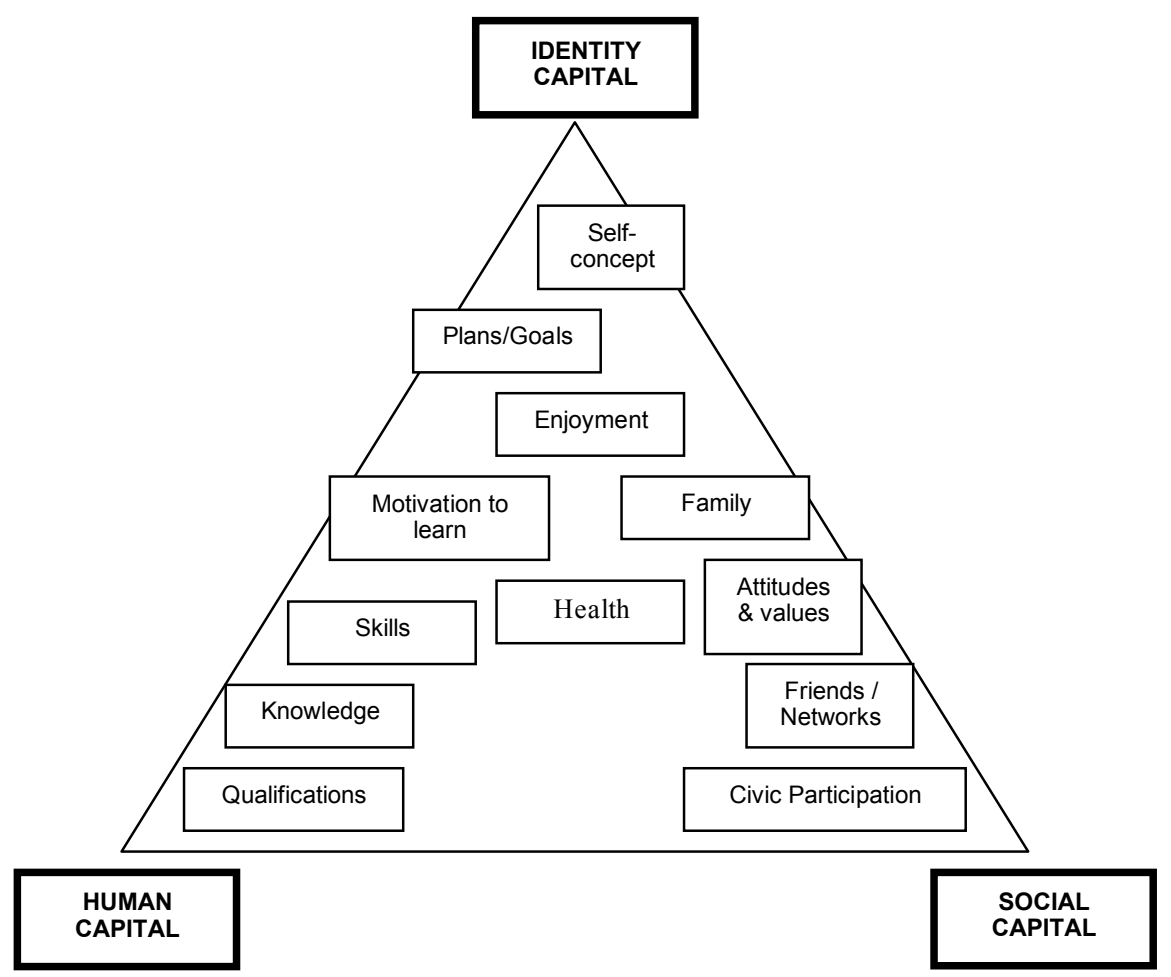

Figure 2: Capitals and capabilities as returns to learning

In reference to Figure 2, the people in this community had a selfconcept that included themselves as readers and as part of the wider world. There was evidence of enjoyment in reading; their connections as a family were strong; they had developed attitudes and values around reading. What was impacting on the development of the Human Capital in the community in respect to literacy, was the development of skills, knowledge and qualifications. Following on with the second model mapped in Figure 3, it is the provision of services that are impacting on capability, which then creates social exclusion. 


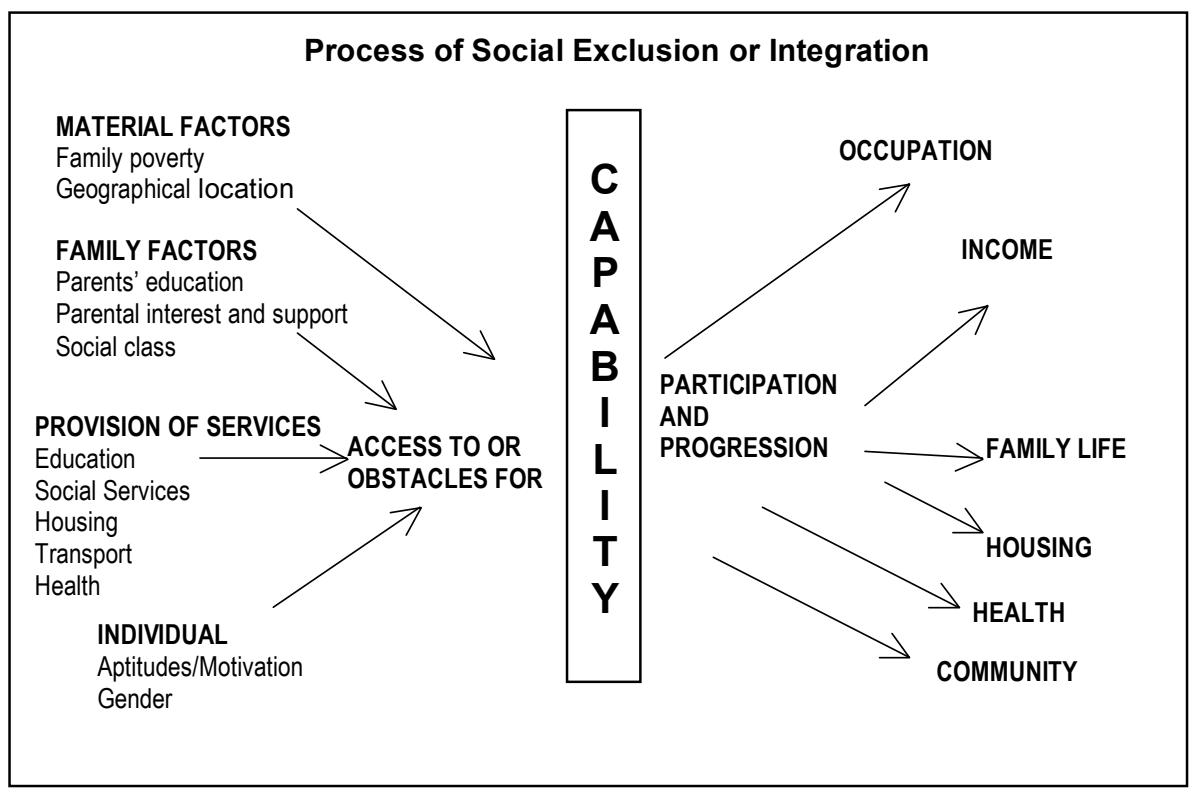

Figure 2: Process of social exclusion or integration

\section{Finding 2: Even though the only books were written in English which was not a first language for them, the children still developed emergent literacy behaviours}

While it may seem obvious that the children will develop emergent literacy behaviours simply by being given books, there has been limited research to date in bilingual situations where the home language is not a written language. Such is the situation here. This means that, whilst it is preferable for the children to have literacy material in their home language, the lack of such materials will not inhibit the development of emergent literacy. It has beenn shown that those books made at playgroup, recounting real experiences and using photographs of family, were valued most in the home.

Thus, when the service is provided, the children will begin their literacy life journey. They are beginning to develop capability which can translate into capital and therefore a stronger community. 


\section{Finding 3: Family literacy in this community is effectively being controlled through the bureaucratic power structures that are in place}

The only observed literacy materials available in this community are owned and controlled by government-run agencies. Forms are filled out in the council office; you can read books in the waiting room at the health centre, and fill in more forms; the children are learning to read and write at school. Individual and family access to, and interaction with literacy, is controlled by those agencies and the individuals who are in the positions of management or control. The nurse at the health centre puts books in the waiting room for people to read - she controls the books. Writing is something that is done only for official business. The school controls the learning. Even the books given out or made during this research project came from a school-run project.

The obstacle created by the withholding of education services in the community will engender social exclusion that impacts much more broadly than a lower literacy rate. While this is perhaps a self-evident truth, it is worthwhile to have it mapped in this way to facilitate the discussion and emphasise the wider implications of the development of literacy by the children. What the authors of this model exhort us to remember is that this is a complex interplay and it is not enough to consider early intervention strategies in isolation from whole community responses.

Poor early educational achievement, reflecting a depleted base for human capital has a strongly cumulative effect. Major efforts should be made to redress initial inequalities, but these are bound to be limited in impact if they are only applied to the initial phase of the lifecourse. This is one of the fundamental weaknesses of educational policy, which focuses too narrowly on initial achievement. (Schuller, Bynner and Feinstein 2004:21)

\section{Implications and conclusion}

It's not enough to say 'We'll catch them up when they start school' because this interventionist approach is an isolated approach that will have little impact on the broader issue at hand, that of community development. Initiatives planned for early literacy intervention must include a broader community approach that ensures there is access to services for everyone. More than this, the control of these services needs to be shifted out of the hands of the bureaucracy and into the hands of the family. Even with good literacy programs running in the schools, there will be limited social and community development without whole community control of literacy. 
In this paper I have told just one story from the desert. There are many more that can be told, if we are prepared to listen. Other possibilities for further research include identifying the capacity and capability within the community surrounding power structures. Just why didn't the Community Management Committee that oversees the store intervene with the employed manager of the store and ensure that there were books, newspapers and magazines for sale?

I have written this paper in order to tell this one story. In this paper, there has been talk of princesses and tarps. In some ways it's all a bit exotic - and as long as you don't live in this reality, there is always the risk that the telling of stories like this one will be just that, an exotic tale from a far-off place. I ask you to take a moment to think of the implications of this story and, if you should ever be in a position to bring about the kind of change required, to remember this story and give the literacy back to the community - princesses and all.

\section{References}

Barratt-Pugh, Kaylene and Rohl, Mary (2000) Literacy Learning in the Early Years, Allen \& Unwin, Crows Nest, NSW.

Bat, Melodie (2003) A Tarp, a Troopie and a Teddy Bear: Fostering early literacy practices in targeted remote Aboriginal Communities in Central Australia, unpublished thesis, Charles Darwin University.

Christie, Michael (1989) Literacy, Genocide and the Media, The Aboriginal Child at School, vol 17, no 9, pp 44-47.

Dunn, Myra (1997) Learning to be Literate, unpublished thesis, University of New England.

Dunn, Myra (1999) Tracking Literacy Development in an Aboriginal Community: Summary of a research project, The Australian fournal of Language and Literacy, vol 22, no 2, pp 103-119.

Durre, A (1985) What to do Before the Formal Teaching of Reading Begins, The Aboriginal Child at School, vol 13, no 1, pp 18-30.

Hill, Susan, Comber, Barbara, Louden, William, Rivalland, Judith and Reid, Joanne (1998) 100 Children Go to School - Connections and disconnections in literacy development in the year prior to school and the first year of school, three volumes, Department of Employment, Education, Training and Youth Affairs, Canberra.

Institute for Aboriginal Development (1997) English and Vernacular Literacy in Central Australia, a discussion paper presented by the Curriculum Development Unit, Institute for Aboriginal Development, October.

McNaughton, Stuart (2002) Meeting of Minds, Learning Media, New Zealand. 
Nicholls, Christine and Harris, Stephen (1996) Learning to Read Using the Lap Method, Education Australia, no 33, pp 31-33.

Northern Territory Department of Education (1999) Learning Lessons: An independent review of Indigenous education in the Northern Territory, Northern Territory Government, Darwin.

Northern Territory Department of Employment, Education and Training (2006) Indigenous Languages and Culture in Northern Territory Schools $2004-$ 2005, Northern Territory Government, Darwin.

Reid, Lyon (1997) Statement before the Committee on Education and the Workforce, United States House of Representatives, Child Development and Behaviour Branch, National Institute of Child Health and Human Development, Thursday July 10.

Schuller Tom, Bynner, John and Feinstein, Leon (2004) Capitals and Capabilities, Centre for Research on the Wider Benefits of Learning, retrieved on 17 August 2007 from www.learningbenefits.net

Walton, Christine (1987) Learning to Write: A case study, The Aboriginal Child at School, vol 15, no 5, pp 3-32.

Wiersma, William (1995) Research Methods in Education, 6th edition, Allyn \& Bacon, Boston. 
